\title{
Complex Teaching Material Production: An Interview
}

public-history-weekly.degruyter.com/9-2021-2/interview-vaihinger/

By

March 25, 2021

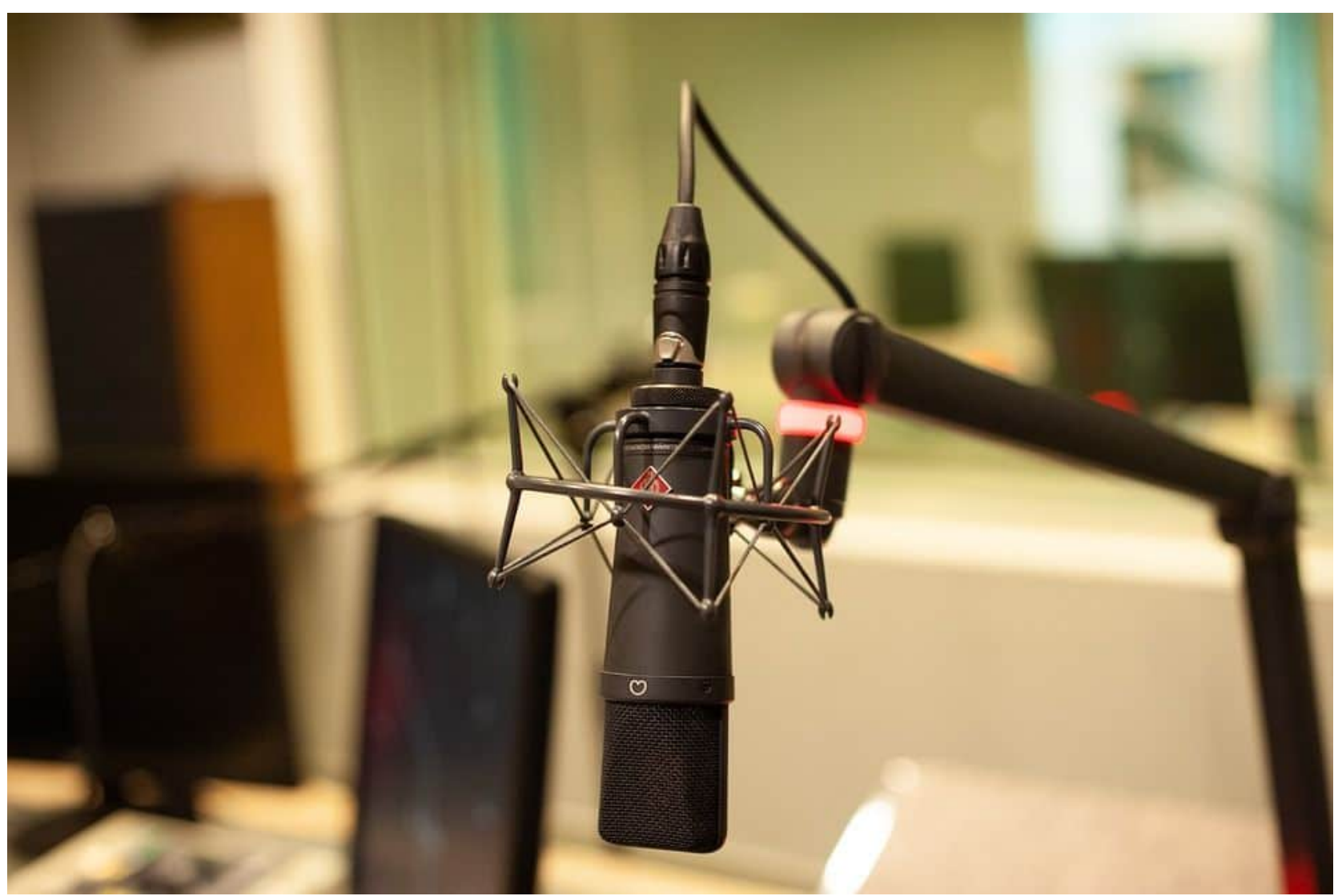

Abstract: An interview with Dirk Vaihinger, member of the Executive Board and Chief Editor of Lehrmittelverlag Zürich. The interview for Public History Weekly was conducted by Peter Gautschi, Christian Bunnenberg and Lukas Tobler.

DOI: dx.doi.org/10.1515/phw-2021-17610.

Languages: English, German

- English

- Deutsch

School history textbooks are discussed by authors, teachers, educational policy makers, history didacticians, historians, public historians, and sometimes also students.

Publishers' employees rarely get a chance to speak. In the following interview, Dirk Vaihinger of Lehrmittelverlag Zürich comments on publishing structures, on digital transformation, on processes of creating teaching materials, on the special role of school history textbooks, and, of course, on the future of the medium. Vaihinger emphasizes that, in the end, a teaching tool is just a teaching tool. The teaching, the teacher who deals with it, remains decisive for the future.

\section{Publishing Structures}


Public History Weekly: Dear Mr. Vaihinger, how does the Swiss teaching materials market structurally differ from those of other countries?

Dirk Vaihinger: In the neighboring countries the structures function similarly to those in Switzerland. There are, however, striking differences with some Eastern European countries. Colleagues there report how the relevant ministries directly intervene in content or pricing policies and curricula, and the dependencies are more massive and changing. Overall, the conditions there are much more difficult, and we also make ourselves aware of that again and again: We are operating on a comparatively very positively supported basis.

The teaching materials market in Switzerland is regulated by the state. What are the advantages and disadvantages of this system?

There are framework conditions for all publishers producing teaching materials such as curricula, the say of the school field, demands on the level of education, data protection requirements, parents' expectations etc., as well as, above all, quality and professionalism demands. Such regulations apply sometimes to a greater, sometimes to a lesser extent to all competitors.

\section{Who are your customers? Are students also among them?}

It's a bit like with other children's books: The buyer is usually not the consumer. However, with teaching materials it is a mixed form, because here the teacher is also a consumer he or she must work with the material, use it, provide it, prepare it. In any case, the customer are the teachers, and they are indeed king with us, even if the municipality or school administration or even an entire canton is the buyer. Fortunately for the consumer, that is the child, the buyer thinks in his sense - thus not exclusively with the question: How easy will this make my teaching? - but also: How do the application competences get into the heads of my students? We generally do not conduct student surveys until secondary school level, rarely with younger candidates. Our experience has simply been that the judgments and opinions in question - in terms of fit, motivation and comprehensibility - are of limited value only.

How do you see the future of Open Educational Resources? Will this change educational publishers?

I think that's to be feared. I say "fear", not because this automatically makes the offerings worse, but because the filtering function, the control of curriculum fit, quality assurance, data protection, educational harmonization, the critical screening of sources, the defense against advertising and attempted influence become the essential task of teaching material work. Personally, I would find that a rather boring business. The fact is that all "open content" has to be paid for by someone. Controlling influence and safeguarding interests one then gladly leaves to the state. But just delegating doesn't get the job done. 


\section{Digital Transformation}

The digital transformation poses major challenges for society as a whole. Where do you see the central fields of action for educational publishers, and in which areas are disruptive consequences for the textbook to be expected?

The term "disruptive" has already been used in connection with digitalization for some time. I happened to do research on language use and pathos formulas in the context of the digitalization of culture already thirty years ago. Evergreens also include "digital revolution," "driving digitalization forward," or the accusation that one has "missed the boat". What has been going on for a generation is not a revolution. But clearly, the change is fundamental. What we are striving for is a state in which a change of media is no longer even really noticed: Depending on the topic, task, competence, form of appropriation, the media form in the teaching material is also chosen. This can be an Escape Room Game just like looking for larvae outside at the pond. And in the end, everything should interlock harmoniously. Of course, this is an ideal state. But we are getting closer ... We want to integrate expensively developed technology then and there, where it has become generally usable and affordable. This can take a while depending on the application think of virtual reality. However, we are always significantly more advanced in development than what is currently being used in schools, simply because the time spans are relatively long.

Digital learning offerings are currently flooding schools. Is the classic, printed teaching material a discontinued model?

"Discontinued model" is somehow similar to "missed the boat." Already 25 years ago there were these podiums, where experts from Amazon and from the technical faculties proclaimed the imminent "end of the book". These people have meanwhile all retired and the book trade is flourishing. In brief: The didactic benefit decides, and this prophetic gesture is simply not credible that there would soon be no more didactically meaningful use for the printed, the haptic, for the hands.

Last year, many schools created a digital offering under great pressure. How did this demand for digital offerings affect Lehrmittelverlag Zürich?

We, in fact, reacted very quickly and made all our digital products freely available for research and school. We have issued these "special licenses" well over 140,000 times in German-speaking Switzerland within just a few months! It is interesting to note that this free gift did not result in any slump in the teaching materials business. This means that the demand was indeed enormously high. But things have accelerated on other ends as well. For example, we have built distance learning courses in the short term, for informational and introductory sessions and as a consulting format. We now maintain this as standard with YouTube videos, chat forums and all kinds of mixed forms. A lot of that will stick, because you save time and travel. Here, too: hybrid is the key. But overall, everything is becoming more digital, including distribution channels and, of course, internal company processes are changing, as in any manufacturing industry. 


\section{Emergence Processes}

On what occasions do new teaching materials emerge?

Actually, it always emerges from the needs of the school field. We have evaluations by the teachers' associations, some of which are fixed on a rotational basis, but there are also other evaluation bodies, teaching materials commissions, changes to the curriculum, new combinations of subjects etc. We respond to these needs, clarify together with the school field and research what is needed, and then begin to probe, plan, calculate.

What quality assurance options do you use at the publishing house during the development of the teaching materials and during their use in everyday school life?

Quality assurance is guaranteed with us by educational policy requirements, primarily through the participation of practice and research. The author teams usually come from these areas. In addition, there are practice and subject support groups, trial classes, and from the very beginning the associations, commissions, elementary school offices and other interest groups (for example, on special support or transfer issues, vocational training or higher education) are involved. That's the content side of it. However, I would like to emphasize that our quality also lies in the production: very good illustration, clean rights clearance, printing and material, editing etc. The fact also that we link as little as possible externally and produce as much as possible ourselves in terms of media is also a quality assurance measure. Quality is our competitive advantage, and we place a correspondingly high value on it.

\section{School History Textbooks}

School history textbooks are increasingly criticized for presenting the history of the majority society from a mostly political and event-historical perspective with their contents. Do you also face this criticism?

After all, as publishing house, we are responsible for the content of the teaching materials, and that's a good thing for a number of reasons. And we also provide a whole set of guidelines to ensure that our teaching materials are politically neutral, antidiscriminatory, respectful of diversity, and emphasize sustainability, among other things. Much of this is in the curriculum, but for others we have our own checklists and catalogs of specifications. But I still have great respect for the task of calmly and reasonably presenting and dealing with certain topics in class. History teaching materials in particular are under suspicious scrutiny. Subject-specific didactics and history must, in fact, inevitably represent certain positions with regard to selection, scope, perspectives, and focal points. Not easy, it seems to me. After all, the authors should not just anxiously develop their ideas.

School and teaching materials should be present-oriented and related to the life world. At the same time, printed school history textbooks cannot provide any topicality at all. Are there any strategies for dealing with this challenge from the perspective of the teaching materials publisher? 
Our program includes instructionally guided teaching tools, and as regards competence building, specific steps are needed to ensure progression, consolidation, repetition, and so on. These custom-fit elements can often not easily be replaced by current topics. On this point, the teacher is still asked to fill the gaps - which we leave open extra for this purpose.

\section{Future}

What fears and what wishes do you have for the teaching materials of the future?

The demands of practice on teaching materials have grown continuously. Not least because the demands of society on the practice are also becoming ever greater - cost pressure, parental expectations, ensuring integration and connections, Pisa comparison, large gap in individualization, mapping social diversity. All this makes the production of teaching materials complex, but also exciting. Ideally, we would like to offer everything. In the end, however, a teaching tool is just a teaching tool. The teaching, the teacher who deals with it, will remain decisive for the future.

Dear Mr Vaihinger, thank you for the interview.

Image Credits

Microphone in a recording studio (C) Andrzej Rembowski via Pixabay.

Recommended Citation

Bunnenberg, Christian, Peter Gautschi, and Lukas Tobler: Complex Teaching Material Production: An Interview. In: Public History Weekly 9 (2021) 2, DOI: dx.doi.org/10.1515/phw-2021-17610.

Editorial Responsibility

Christian Bunnenberg / Lukas Tobler / Peter Gautschi (Team Lucerne)

Über Schulgeschichtsbücher diskutieren Autor:innen, Lehrer:innen, Bildungspolitiker:innen, Geschichtsdidaktiker:innen, Historiker:innen, Public Historians und manchmal auch Schüler:innen. Verlagsmitarbeitende kommen selten zu Wort. Im folgenden Interview nimmt Dirk Vaihinger vom Lehrmittelverlag Zürich Stellung zu Verlagsstrukturen, zur digitalen Transformation, zu Entstehungsprozessen von Lehrmitteln, zur besonderen Rolle von Schulgeschichtsbüchern und natürlich zur Zukunft des Mediums. Vaihinger betont, dass am Ende ein Lehrmittel nur ein Lehrmittel sei. Die Lehre, die Lehrperson, die damit umgeht, bleibe zukunftsentscheidend.

\section{Verlagsstrukturen}

Public History Weekly: Sehr geehrter Herr Vaihinger, wie unterscheidet sich der Schweizer Lehrmittelmarkt strukturell von denjenigen anderer Länder? 
Dirk Vaihinger: In den angrenzenden Ländern funktionieren die Strukturen ähnlich wie in der Schweiz. Markante Unterschiede gibt es hingegen zu einigen osteuropäischen Ländern. Die Kolleg:innen dort berichten, wie von den zuständigen Ministerien direkt in den Inhalt, die Preispolitik und in die Lehrpläne eingegriffen wird. Die Abhängigkeiten sind massiver und wechselnd. Insgesamt herrschen dort deutlich schwierigere Bedingungen, und das machen wir uns auch immer wieder bewusst: Wir operieren auf einer vergleichsweise sehr positiv gestützten Basis.

Der Lehrmittelmarkt in der Schweiz ist staatlich reguliert. Welches sind die Vor- und Nachteile dieses

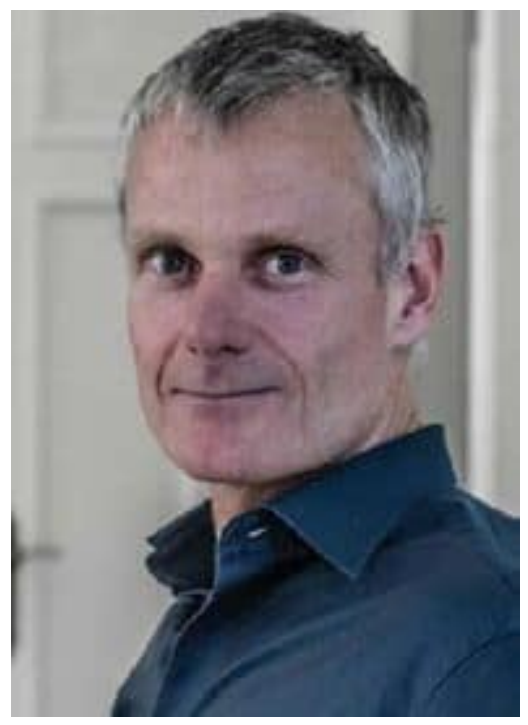
Systems?

Es gibt ja für alle lehrmittelproduzierenden Verlage Rahmenbedingungen wie Lehrpläne, die Mitsprache des Schulfelds, Ansprüche an das Bildungsniveau, DatenschutzAnforderungen, Erwartungen der Eltern usw. sowie vor allem auch Qualitäts- und Professionalitätsansprüche. Solche Regularien gelten mal mehr, mal weniger für alle Wettbewerber.

\section{Wer sind Ihre Kund:innen? Gehören Schüler:innen auch dazu?}

Es ist ein bisschen wie auch sonst mit Kinderbüchern: Der Käufer ist in der Regel nicht der Konsument. Allerdings ist es bei Lehrmitteln eine Mischform, denn hier ist auch die Lehrperson Konsument - sie muss mit dem Material arbeiten, es nutzen, bereitstellen, herrichten. Kunde ist auf jeden Fall die Lehrerschaft, und die ist tatsächlich bei uns König, auch wenn die Gemeinde oder Schulpflege oder gar ein ganzer Kanton der Einkäufer ist. Zum Glück des Konsumenten, also des Kindes, denkt der Käufer in seinem Sinne - also nicht ausschließlich mit der Frage: Wie einfach wird dadurch mein Unterricht?, sondern auch: Wie gelangen die Anwendungskompetenzen in die Köpfe meiner Zöglinge? Schüler:innenbefragungen führen wir in der Regel erst in der Oberstufe durch, selten bei jüngeren Kandidat:innen. Wir haben einfach die Erfahrung gemacht, dass die betreffenden Urteile und Meinungen - hinsichtlich Passgenauigkeit, Motivation und Verständlichkeit - nur bedingt aussagekräftig sind.

Wie schätzen Sie die Zukunft von Open Educational Resources ein? Wird das Bildungsverlage verändern?

Das steht wohl zu befürchten. Ich sage "befürchten”, nicht weil dadurch automatisch die Angebote schlechter werden, sondern weil die Filterfunktion, die Kontrolle der Lehrplanpassung, Qualitätssicherung, Datenschutz, die Ausbildungs-Harmonisierung, die kritische Durchleuchtung der Quellen, die Abwehr von Werbung und versuchter Einflussnahme zur wesentlichen Aufgabe der Lehrmittelarbeit wird. Ich persönlich fände das ein eher langweiliges Geschäft. Tatsache ist ja, dass jeglicher "open content” von 
irgendwem bezahlt werden muss. Einflussnahme zu kontrollieren und Interessen zu sichern überlässt man dann gern dem Staat. Aber nur durch Delegieren ist die Arbeit nicht erledigt.

\section{Digitale Transformation}

Die digitale Transformation stellt die gesamte Gesellschaft vor große

Herausforderungen. Wo sehen Sie für Lehrmittelverlage die zentralen Handlungsfelder, und in welchen Bereichen sind disruptive Folgen für das Schulbuch zu erwarten?

Der Begriff "disruptiv" ist im Zusammenhang mit Digitalisierung schon länger im Einsatz. Ich habe zufällig schon vor dreißig Jahren über den Sprachgebrauch und die Pathosformeln im Kontext der Digitalisierung der Kultur geforscht. Evergreens sind auch "digitale Revolution", "Digitalisierung vorantreiben" oder der Vorwurf, man habe den "Anschluss verschlafen". Was schon eine Generation lang andauert, ist keine Revolution. Aber klar, der Wandel ist fundamental. Was wir anstreben ist ein Zustand, in dem ein Medienwechsel gar nicht mehr richtig bemerkt wird: Je nach Thema, Aufgabe, Kompetenz, Aneignungsform wird auch die Medienform im Lehrmittel gewählt. Das kann ein Escape Room Game genau so sein wie draußen am Tümpel Larven suchen. Und am Ende soll alles harmonisch ineinandergreifen. Natürlich ist das ein Idealzustand. Aber wir nähern uns an. Wir wollen teuer entwickelte Technik dann und dort einbinden, wo sie allgemein brauchbar und bezahlbar geworden ist. Das kann je nach Anwendung eine Weile dauern - denken Sie an die virtuelle Realität. Wir sind allerdings beim Entwickeln immer deutlich avancierter als das, was gerade in der Schule eingesetzt wird, einfach weil die Zeitspannen relativ groß sind.

Aktuell überfluten digitale Lernangebote die Schulen. Ist das klassische, gedruckte Lehrmittel ein Auslaufmodell?

"Auslaufmodell" ist so ähnlich wie "Anschluss verpasst". Schon vor 25 Jahren gab es diese Podien, wo Expert:innen von Amazon und von den technischen Fakultäten das baldige "Ende des Buches" proklamierten. Diese Leute sind mittlerweile alle pensioniert und der Buchhandel blüht. Kurz: Der didaktische Nutzen entscheidet. Und diese prophetische Geste ist einfach nicht glaubwürdig, dass es für Gedrucktes, Haptisches, für die Hände demnächst keinen didaktisch sinnvollen Einsatz mehr gäbe.

Im letzten Jahr haben viele Schulen unter großem Druck ein digitales Angebot erstellt. Wie wirkte sich diese Nachfrage nach digitalen Angeboten auf den Lehrmittelverlag Zürich aus?

Wir haben tatsächlich sehr schnell reagiert und alle unsere digitalen Produkte für Forschung und Schule frei zugänglich gemacht. Diese "Sonderlizenzen" haben wir innert weniger Monate in der Deutschschweiz weit über 140.000 mal vergeben! Interessant ist, dass diese Gratisgabe keinerlei Einbruch im Lehrmittelgeschäft zur Folge hatte. Das heißt, der Bedarf war tatsächlich enorm hoch. Die Dinge haben sich aber auch an anderen Enden beschleunigt. Zum Beispiel haben wir kurzfristig Fernkurse aufgebaut, für Informations- und Einführungsveranstaltungen und als Beratungsformat. Das pflegen wir 
mittlerweile standardmäßig mit Youtube-Videos, Chatforen und allerlei Mischformen. Davon wird vieles hängen bleiben, denn man spart Zeit und Anfahrtsweg. Auch hier: hybrid ist Trumpf. Aber insgesamt wird alles digitaler, auch die Vertriebswege und natürlich die betriebsinternen Abläufe sind im Wandel, wie in jedem produzierenden Gewerbe.

\section{Entstehungsprozesse}

Aus welchen Anlässen entstehen neue Lehrmittel?

Eigentlich entsteht es immer aus den Bedürfnissen des Schulfelds. Es gibt bei uns Evaluationen durch die Lehrerverbände, die sind zum Teil turnusmäßig festgeschrieben, es gibt aber auch andere Prüfinstanzen, Lehrmittelkommissionen, Änderungen des Lehrplans, neue Fächerkombinationen usw. Wir reagieren auf diese Bedürfnisse, klären gemeinsam mit Schulfeld und Forschung ab, was es braucht, und fangen dann an zu sondieren, zu planen, zu rechnen.

Welche Möglichkeiten der Qualitätssicherung nutzen Sie im Verlag während der Entwicklung der Lehrmittel und während der Nutzung im Schulalltag?

Die Qualitätssicherung ist bei uns durch bildungspolitische Vorgaben gewährleistet, in erster Linie durch die Teilnahme von Praxis und Forschung. Die Autor:innenteams kommen in der Regel aus diesen Bereichen. Daneben gibt es Praxis- und Fachbegleitgruppen, Erprobungsklassen, und von Anfang an sind die Verbände, Kommissionen, Volksschulämter und andere Interessengruppen - etwa zu spezieller Förderung oder Übertrittsfragen, zur Berufsbildung oder höheren Schulbildung eingebunden. Das ist die inhaltliche Seite. Ich lege aber Wert auf die Feststellung, dass unsere Qualität auch in der Produktion liegt: sehr gute Illustration, saubere Rechteabklärung, Druck und Material, Lektorat usw. Auch die Tatsache, dass wir möglichst wenig extern verlinken und medial möglichst viel selber produzieren, ist eine Qualitätssicherung. Qualität ist unser Wettbewerbsvorteil, und entsprechend viel Wert legen wir darauf.

\section{Schulgeschichtsbücher}

Immer häufiger wird an Schulgeschichtsbüchern die Kritik geäußert, dass sie mit ihren Inhalten die Geschichte der Mehrheitsgesellschaft aus zumeist politik- und ereignisgeschichtlicher Perspektive darstellen. Sind Sie auch mit dieser Kritik konfrontiert?

Wir sind ja als Verlag verantwortlich für den Inhalt der Lehrmittel, und das ist aus verschiedenen Gründen gut so. Und wir geben auch eine ganze Reihe von Vorgaben, damit unsere Lehrmittel politisch neutral, antidiskriminierend, Diversität achtend und Nachhaltigkeit betonend u.a.m. sind. Vieles davon steht im Lehrplan, für anderes haben wir eigene Prüflisten und Vorgabenkataloge. Aber ich habe dennoch großen Respekt vor der Aufgabe, gewisse Themen ruhig und vernünftig im Unterricht darzustellen und abzuhandeln. Vor allem Geschichtslehrmittel stehen unter argwöhnischer Beobachtung. 
Fachdidaktik und Geschichtswissenschaft müssen doch zwangsläufig bestimmte Positionen vertreten punkto Auswahl, Umfang, Sichtweisen, Schwerpunkten. Nicht einfach, scheint mir. Die Verfasser sollen ja nicht nur noch ängstlich ihre Ideen entwickeln.

Schule und Lehrmittel sollen gegenwartsorientiert und lebensweltbezogen sein. Gleichzeitig können gedruckte Schulgeschichtsbücher gar keine Aktualität bieten. Gibt es aus der Perspektive des Lehrmittelverlags Strategien zum Umgang mit dieser Herausforderung?

Unser Programm sind unterrichtsleitende Lehrmittel. Beim Kompetenzaufbau braucht es spezifische Schritte, um Progression, Vertiefung, Wiederholung usw. sicherzustellen. Diese passgenauen Elemente lassen sich oft nicht umstandslos durch tagesaktuelle Themen austauschen. Da ist die Lehrperson weiterhin gefragt, die Lücken zu füllen - die wir zu diesem Zweck ja auch extra offen lassen.

\section{Zukunft}

Welche Befürchtungen und welche Wünsche haben Sie für die Lehrmittel der Zukunft?

Die Ansprüche der Praxis an Lehrmittel sind kontinuierlich gewachsen. Nicht zuletzt deshalb, weil auch die Ansprüche der Gesellschaft an die Praxis immer größer werden Kostendruck, Elternerwartungen, Integration und Anschlüsse sicherstellen, PisaVergleiche, große Schere bei der Individualisierung, Abbildung gesellschaftlicher Vielfalt u.a.m. Das macht die Lehrmittelproduktion komplex, aber auch spannend. Am liebsten würden wir alles bieten. Am Ende ist ein Lehrmittel aber nur ein Lehrmittel. Die Lehre, die Lehrperson, die damit umgeht, wird zukunftsentscheidend bleiben.

Sehr geehrter Herr Vaihinger, wir danken Ihnen für das Gespräch.

\section{Abbildungsnachweis}

Mikrofon in einem Tonstudio (C) Andrzej Rembowski via Pixabay.

Empfohlene Zitierweise

Bunnenberg, Christian, Peter Gautschi, and Lukas Tobler: Komplexe Lehrmittelproduktion: Ein Interview. In: Public History Weekly 9 (2021) 2, DOI: dx.doi.org/10.1515/phw-2021-17610.

Translated by Kurt Brügger swissamericanlanguageexpert https://www.swissamericanlanguageexpert.ch

Editorial Responsibility

Copyright (c) 2020 by De Gruyter Oldenbourg and the author, all rights reserved. This work may be copied and redistributed for non-commercial, educational purposes, if permission is granted by the author and usage right holders. For permission please contact the editor-in-chief (see here). All articles are reliably referenced via a DOI, which includes all comments that are considered an integral part of the publication. 
The assessments in this article reflect only the perspective of the author. PHW considers itself as a pluralistic debate journal, contributions to discussions are very welcome. Please note our commentary guidelines (https://public-history-weekly.degruyter.com/contribute/).

Categories: 9_(2021)_2

DOI: $\underline{\text { dx.doi.org/10.1515/phw-2021-17610 }}$

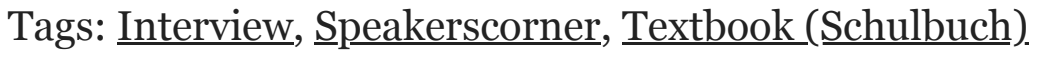

